\title{
Aspects of the Hydrogeology of southern Campeche and Quintana Roo, Mexico
}

\author{
Aspectos de la hidrogeología del sur de Campeche y Quintana Roo, México
}

Eugene G. Perry ${ }^{1}$, Rosa M. Leal-Bautista ${ }^{3, *}$, Guadalupe Velázquez-Olimán ${ }^{2}$, Joan A. Sánchez-Sánchez ${ }^{4}$, Nikklas Wagner ${ }^{5}$

\begin{abstract}
Northern Illinois University, Geology and Environmental Geosciences, Emeritus, DeKalb, Illinois 60115, United States.

2 Centro de Innovación e Investigación para el Desarrollo Sustentable, Javier Rojo Gómez, Mza. 9, Lote 1, Local F, Puerto Morelos, 77580, Quintana Roo, Mexico.

Centro de Investigación Cientí ica de Yucatán, A.C., Unidad de Ciencias del Agua, Calle 8, No. 39, Mza. 29, SM 64, Cancún, 77524, Quintana Roo, Mexico.
\end{abstract}

${ }^{4}$ El Colegio de la Frontera Sur, Departamento de Ciencias de la Sustentabilidad, Grupo de Biotecnología Ambiental, Unidad Chetumal, Av. Centenario km 5.5, 77014, Chetumal, Quintana Roo, Mexico.

${ }^{5}$ Chemtech Services, Inc., 20648 Gaskin Dr., Lockport, IL 60446, United States.

* Corresponding author: (R. Leal-Bautista) rleal@cicy.mx

How to cite this article:

Perry, E.C., Leal-Bautista, R. M., VelázquezOlimán, G., Sánchez-Sánchez, J.A., Wagner, N., 2021, Aspects of the Hydrogeology of southern Campeche and Quintana Roo, Mexico: Boletín de la Sociedad Geológica Mexicana, 73 (1), A011020. http://dx.doi. org/10.18268/BSGM2021v73nla011020

Manuscript received: March 24, 2020

Corrected manuscript received: September 27, 2020

Manuscript accepted: October 1, 2020

Peer Reviewing under the responsibility of Universidad Nacional Autónoma de México.

This is an open access article under the CC BY-NC-SA license(https://creativecommons.org/licenses/by-nc-sa/4.0/)

\section{ABSTRACT}

This paper explores strong indirect evidence for existence of a previously unrecognized deep groundwater aquifer in southern Quintana Roo, adjacent parts of Campeche, and (probably) northern Belize. The region contains rocks of Cretaceous-to-Holocene age, including: 1) an up-thrust block of the late Cretaceous carbonate known in Belize as the Barton Creek Formation, which is the oldest formation exposed in the Mexican Yucatán Peninsula, 2) the Cretaceous/ Paleogene Albion Formation consisting of weakly consolidated Chicxulub impact air-fall deposits, 3) the Paleocene-Eocene Icaiche Formation, containing a massive 25-35 m thick gypsum member that crops out over an estimated area of more than $10,000 \mathrm{~km}^{2}$ in the elevated interior region of the northern lowlands, and 4) younger rocks of relatively low permeability that flank the region on the east. Hydrogeology is dominated by groundwater and surface flow in and adjacent to the Rio Hondo Fault Zone (RHFZ) and by recharge in the elevated interior region. Groundwater in the elevated region has a high sulfate concentration and is approximately saturated with gypsum dissolved from the Icaiche Formation. High-sulfate groundwater and river water with a slightly lower gypsum saturation index than in the elevated region also occurs in the RHFZ, but no water of comparably high sulfate content is present elsewhere in the study area. This suggests that the elevated region is a recharge zone for high-sulfate groundwater carried eastward beneath a $50 \mathrm{~km}$ gap by a deep, previously unrecognized aquifer and then discharged into the RHFZ. Based on chemistry of chloride, sulfate and other ions it is proposed here that a deep aquifer comprising the strongly weathered upper surface of the Barton Creek Formation plus the overlying weakly consolidated Albion Formation connects the elevated recharge area with the RHFZ discharge area. If this composite permeable zone does extend westward beneath the elevated recharge zone, it is probably an excellent aquifer.

Keywords: Hydrogeology, Icaiche Formation, Sulfates, Deep aquifer, Yucatan Peninsula.

\section{RESUMEN}

Este documento, explora la existencia indirecta de un acuífero profundo no reconocido previamente en el sur de Quintana Roo, partes adyacentes de Campeche, y probablemente norte de Belice. La región contiene rocas del Cretáceo al Holoceno, incluyendo: 1) un bloque elevado carbonatado del Cretácico conocido en Belice como la Formación Barton Creek, la cual es la Formación más antigua expuesta en la parte mexicana de la Peninsula de Tucatán, 2) la Formación Albión Cretácico/Paleógeno consiste en depósitos pobremente cementados de residuos aéreos del Impacto del Chicxulub, 3) Formación Icaiche PaleocenoEoceno, notable por su componente masivo de yeso (25-35 $m$ de espesor) un afloramiento aproximado de $10,000 \mathrm{~km}^{2}$ en la Región Interior Elevada (RIE) de las tierras bajas del norte, y 4) rocas más jóvenes de permeabilidad relativamente baja, en el flanco este de dicha región. Hidrogeológicamente dominan flujos superficiales y de agua subterránea adyacentes a la Zona de Falla del Rio Hondo (ZFRH) y la recarga en la RIE. Debido al yeso disuelto de la Formación Icaiche el agua subterránea está casi saturada en sulfato. A su vez esta concentración de sulfato en agua subterránea de ZFRH, es menor comparada con el agua de rio; ambas indican un indice de saturación de yeso menor y diferente al de la RIE. Sin embargo, no se detectan contenidos tan altos de sulfato en otras partes de la zona de estudio. Basados en la geoquimica de los iones cloruro y sulfato se propone la existencia de un acuífero profundo que comprende la superficie superior fuertemente erosionada de la Formación Barton Creek, sobrecubierta por la consolidación débil de la Formación Albion conectando la región elevada con la descarga en ZFRH. Si esta zona permeable compuesta estará representando un excelente acuifero extendiendose hacia el oeste debajo de la zona de recarga de la región elevada.

Palabras clave: Hidrogeología, sulfatos, Formación Icaiche, acuífero profundo, Península de Yucatán. 


\section{Introduction}

In this paper we present chemical data from groundwater, especially its sulfate ion concentration, as tracers, and we assert that these data provide strong indirect evidence for the existence of a previously unrecognized deep groundwater flow path in the southeastern part of the Mexican Yucatán Peninsula (henceforth MY) adjacent to, and probably extending into, northern Belize. The region is an elevated zone of recharge encompassing much of the southeastern part of Campeche state and adjacent parts of southern Quintana Roo. There, the Paleocene-Eocene Icaiche Formation is present at the surface over a wide area; and, because that formation contains massive and extensive beds of highly soluble gypsum $\left(\mathrm{CaSO}_{4} \cdot 2 \mathrm{H}_{2} \mathrm{O}\right)$, it is a major regional source of groundwater sulfate ions.

Although the Icaiche Formation is widely exposed, relatively little is known about the formation because a thick cover of tropical vegetation combined with a low population density in the region and a correspondingly sparce road network make detailed geologic observation difficult (Perry, et al., 2019). Nevertheless, geologic research in this largely undeveloped southern part of MY is important and warrants broad interest because, as pointed out by Perry et al., (2019), the Icaiche Formation is present in the subsurface beneath much of MY far beyond its outcrop area. It contains both thick beds of highly soluble, massive gypsum as well as argillite layers of low permeability, and the formation strongly influences geomorphology and groundwater geochemistry in populous parts of the northern Peninsula. Hence, detailed study of the Icaiche Formation and its geologic associations in this southern area where its outcrops are exposed and can be examined directly is an effective way of developing an increased understanding of important aspects of the hydrogeology and geomorphology of the entire MY.

In a companion to this paper, Perry et al., (2019) discussed important hyrogeologic and geomorphic effects that massive gypsum beds of the Icaiche Formation have produced both in and adjacent to its area of outcrop. In this paper we extend the discussion of how the geology and geochemistry of the Icaiche Formation has affected more populous regions by examining a specific case in which we examine the chemistry of high-sulfate groundwater in the elevated recharge area where gypsum of the formation is present, and we then compare that groundwater to ground and surface water chemistry in a lowland area more than 50 $\mathrm{km}$ away -- where groundwater of similarly high sulfate content is discharging into the Rio Hondo Fault Zone (henceforth RHFZ), (Figure 1). We also establish that no high-sulfate surface water or shallow groundwater is present in the wide intervening zone between the area of Icaiche gypsum outcrops and the RHFZ. Finally, we conclude that the remarkably similar high-sulfate water chemistry in the Icaiche recharge area is the probable direct source of high-sulfate water in the RHFZ. From what is known about regional geology we then suggest that the two areas are connected by a deep aquifer consisting of a weathered upper Cretaceous carbonate surface overlain by weakly consolidated air-fall debris of the K-Pg Chicxulub impact event as we discuss further in Section 5.1.

\subsection{HYDROGEOLOGIC GONTRAST BETWEEN NORTHERN AND SOUTHERN AQUIFER SYSTEMS OF THE MY PENINSULA: THE TIGUL FAULT}

The WNW-ESE trending Ticul Fault (Figure 1) serves as a useful but inexact boundary between the northern and southern hydrogeologic regions of MY. The northern system is discussed by numerous researchers beginning with classic papers by William Back, Bruce Hanshaw, and associates: Back and Hanshaw, 1970; Hanshaw and Back, 1980; Back et al., 1979 and Back et al., 1986 as well as later papers such as those of Bauer-Gottwein et al., 2011; Marin, 1990; Perez-Ceballos et al., 2012; Perry et al., 2002; Perry et al., 2009; Perry et al., 2011; Socki et al., 2002; Stoessell et al., 1989; Tulaczyk et al., 1993; Ward et al., 1985. Except for fringe zones on the coast and near the Ticul Fault, the northern hydrogeologic system is quite homogeneous, consisting of a large freshwater 
lens floating on a saline intrusion directly connected to the ocean. Details of northern system hydrogeology are noteworthy here only as an opportunity for us to emphasize that the southern aquifer system, south of the Ticul Fault is very different. Our focus here is on the south.

As noted by Perry et al., (2019), with the exception of a border zone near the Ticul Fault, the aquifer system to the south is heterogeneous, with numerous examples of surface and near-surface perched water tables supported by argillite layers. There is no evidence for a saline intrusion in the south except near the fault and the probable extension of the fault to the east. The dominant rocks cropping out in the south-central area of the MY are part of the Icaiche Formation, overlain to the north by those of the Chichen Itza Formation (Figure 1). Icaiche Formation rocks contain a significant percentage of argillite, and also contain a layer of massive gypsum that is estimated to be 25-35 $m$ thick and to crop out over an estimated area of $10,000 \mathrm{~km}^{2}$ (Perry et al., 2019). Velazquez (1986) was the first researcher to point out the importance of gypsum in the Icaiche Formation to the groundwater geochemistry of MY. Subsequently, Icaiche gypsum has also indirectly been traced in the subsurface as far north as Cenote Xcolac, which is $160 \mathrm{~km}$ away from the nearest Icaiche Formation outcrop (Socki, 1984; Socki et al., 2002) discussed further in Perry et al., 2009, Perry et al., 2018 and Perry et al., 2019.

The important practical differences in the hydrology of the regions north and south of the Ticul Fault can be seen from the fundamentally different survival techniques for water management developed by the Maya who settled the two regions over two millenia ago as is described in many papers, referenced, for example in Dunning et al., 2012 and Beach et al., (2015).

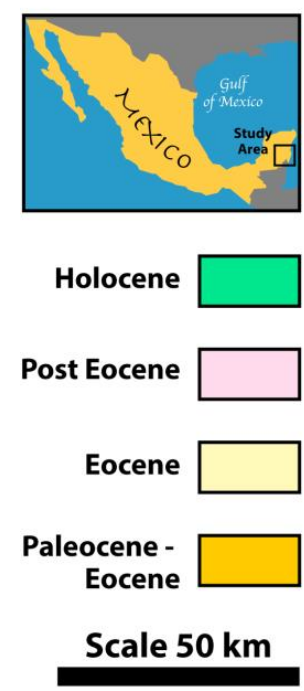

Scale 50 km

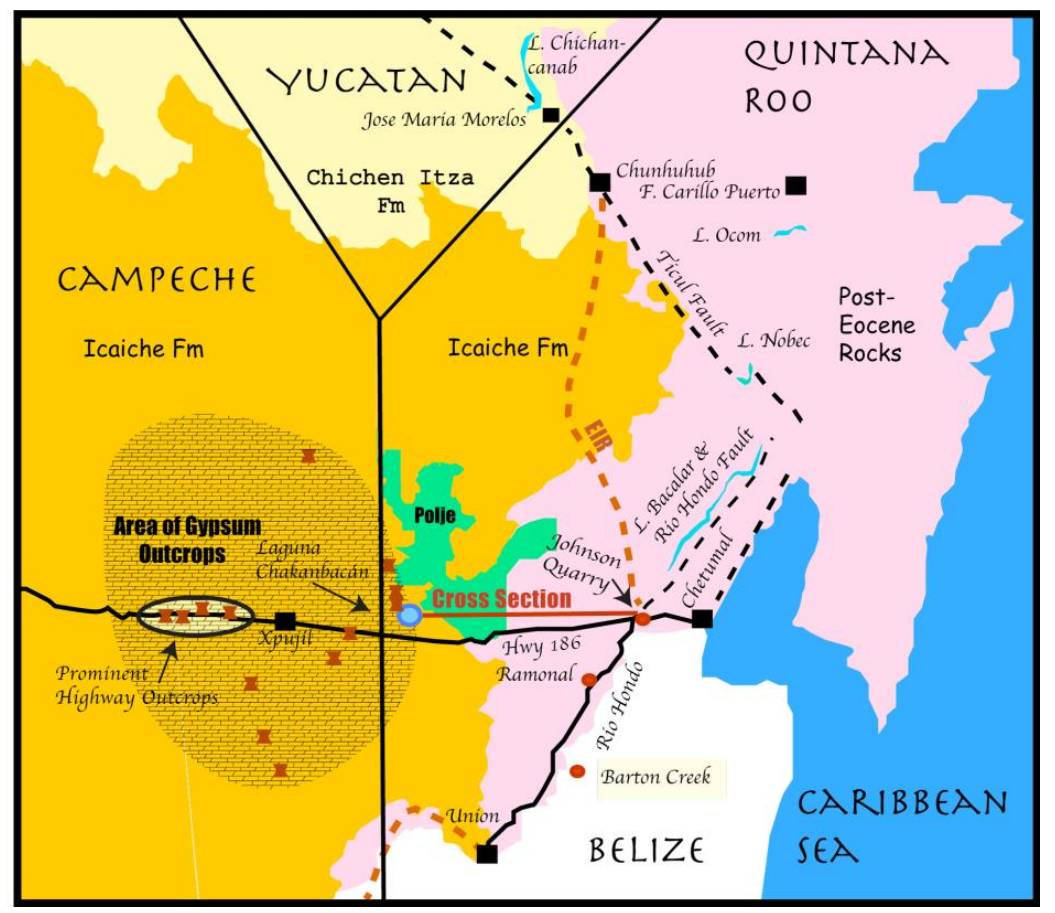

Figure 1 Geologic map of the southeastern Mexican Yucatán Peninsula (MY) showing the outcrop area of the Icaiche Formation and the Chichen Itza Formation in relation to outcrops of Miocene and younger rocks (from SGM, 2007) as well as relevant outcrops of the Albion and Barton Creek Formations (Pope et al., 2005) discussed in the text. The eastern boundary of the Elevated Interior Region (EIR) is shown. The region extends into Guatemala and Belize to the south. Its entire outcrop area within Mexico is shown in Perry et al. (2019), a companion paper that discusses additional powerful influences on the geomorphology and hydrogeology of MY by the Icaiche Formation. 
Whereas those in the north had access to a regional fresh water lens through cenotes, aguadas, and shallow wells, those Maya who settled in an extensive area south of the fault found that 1) much local groundwater was unsuitable for consumption because of its high sulfate content (from contact with gypsum of the Icaiche Formation) and that 2) additionally, some groundwater near the Ticul Fault was too deep to exploit with tools available.

Nevertheless, the southern Maya communities supported a large population for centuries by developing elaborate systems of rainwater storage using locally available sources of impermeable clays Matheny (1976), Dominguez and Folan (1996); Dunning et al., (2012); Dunning et al.,(2016); Beach et al., (2015). Archeologists studying agricultural techniques and hydraulic engineering practices of the southern Maya have dubbed their settlement area the Elevated Interior Region (EIR) Dunning et al.,(2012), and we adapt this name as a useful proxy for the region over which groundwater is contaminated by direct contact with Icaiche gypsum (Figure 1).

\subsection{OBJEGTIVES}

Groundwater that is saturated or nearly saturated with respect to gypsum is generated within the recharge zone of the EIR by contact with lower Paleogene gypsum deposits. The major objectives of this paper are to demonstrate the close chemical similarity of groundwater and surface water of the eastern EIR to the waters of the RHFZ, to demonstrate that regional hydraulic heads are compatible with a recharge/discharge relationship between the two regions and to suggest a hydrologic model (a plumbing system to use an anthropomorphic analog) that is compatible with what is known about the hydrology and stratigraphy of the region. A schematic for our hydrologic model of the system is shown in Figure 3 and is discussed in Section 5.

This paper is based on a review of available information about an understudied region that is of growing importance. It is not a neatly defined study based on years of systematically collected data. Such data do not exist, and, because of

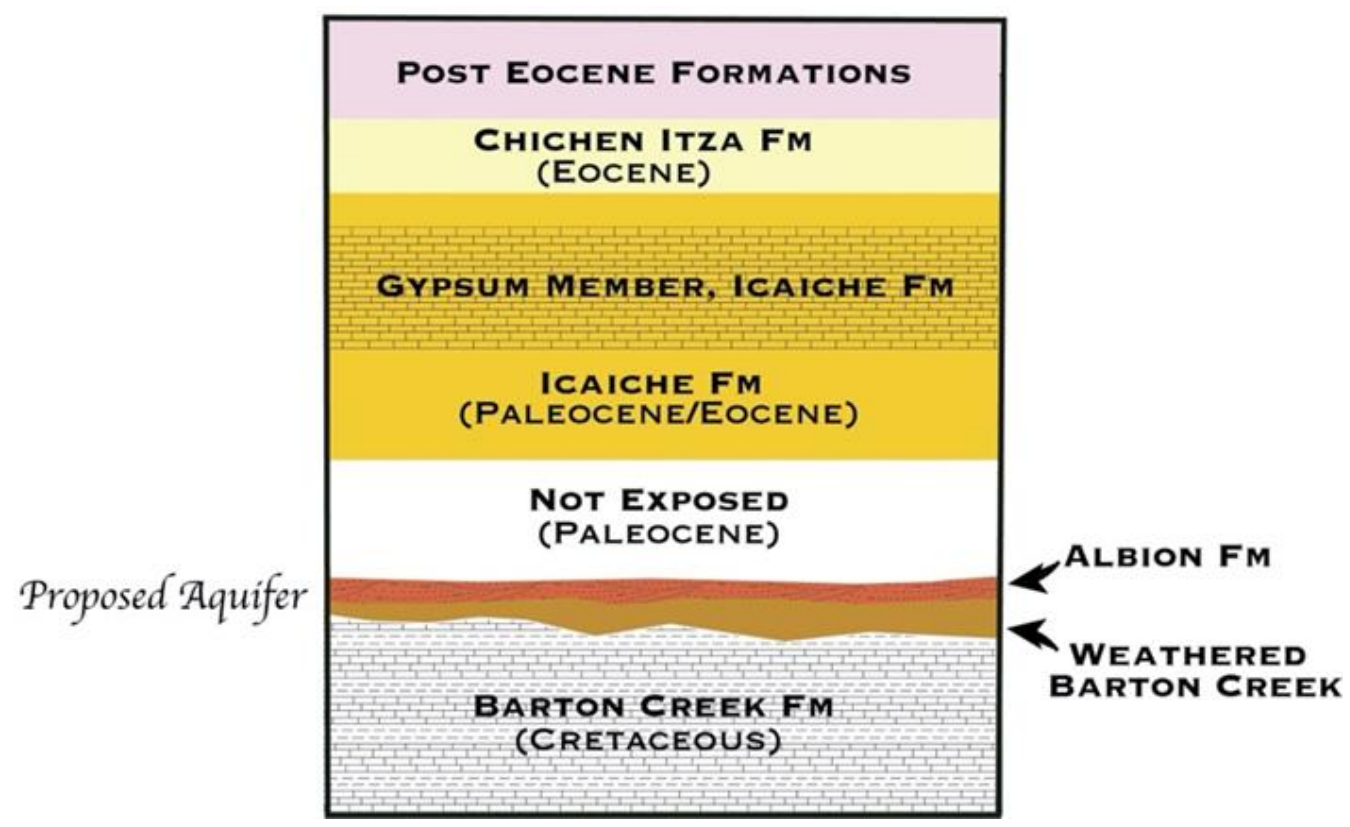


inaccessibility of much of the study area, complete data can be assembled only after a concerted effort over a period measured in years. However, we assert that better understanding of the hydrogeology and geomorphology of the EIR is a key to understanding the hydrogeology and geomorphology of MY.

Furthermore, economic and population pressure, coming both from the north and from the west, as discussed further in Perry et al., (2019), will severely stress the delicate hydrologic system of the region. If the myriad foreseeable and the still unanticipated problems involved are not intelligently addressed in a timely fashion, based on a thorough understanding of regional hydrogeology, an environmental, ecological, and economic catastrophe may result. For these reasons we present this paper and its companion paper: Perry et al., (2019) - not as finished studies but as reviews of available data that are followed by tentative interpretations constituting a set of testable hypotheses that we hope will serve as a template for further research.

\section{Essential aspects of regional stratigraphy}

Discussion of the hydrogeology of the study area requires basic knowledge about three geologic formations: the late Cretaceous Barton Creek Formation, the K-Pg Albion Formation, and the Palecoene-Eocene Icaiche Formation. The Barton Creek and the Icaiche Formations have had a major influence on groundwater movement in the region but have received little attention in the context of hydrogeology.

In evaluating water analyses from the northeastern part of the study area we shall have occasion to discuss briefly the influence of a local argillaceous facies of the Miocene/Pliocene Carrillo Puerto Formation. That formation is a major carbonate aquifer farther north, but, as discussed in more detail by Perry et al., 2019, in east central Quintana Roo, south of the town of Felipe Carrillo Puerto, the Carrillo Puerto Formation has acted as an aquitard, partially isolating surface water flow from the underlying groundwater system.

In addition to the relevant geologic formations, part of an ancient fault system that extends along the entire eastern coastal area of MY acts as an important regional groundwater conduit. (Tulaczyk et al., 1993; Bauer-Gotwein et al., 2011).

The Paleocene-Eocene Icaiche Formation, the dominant rock type exposed at the surface in much of the Mexican EIR (Figure 1), contains thoroughly recrystallized carbonate rock together with marl and abundant bedded gypsum. The formation name was assigned (Butterlin and Bonet, 1960) during a regional field study of the area undertaken by Bonet and Butterlin (B and B) between the years 1958-1960, a time when geologic exploration of the area was particularly challenging because much of the EIR was heavily wooded and was crossed by few roads (a situation that is not completely different today). B and B were successful in mapping the area in large part because their project took place just at the time a road crew was cutting the east-west Mexican Highway 186 across the center of the area of Icaiche outcrops and through heavily

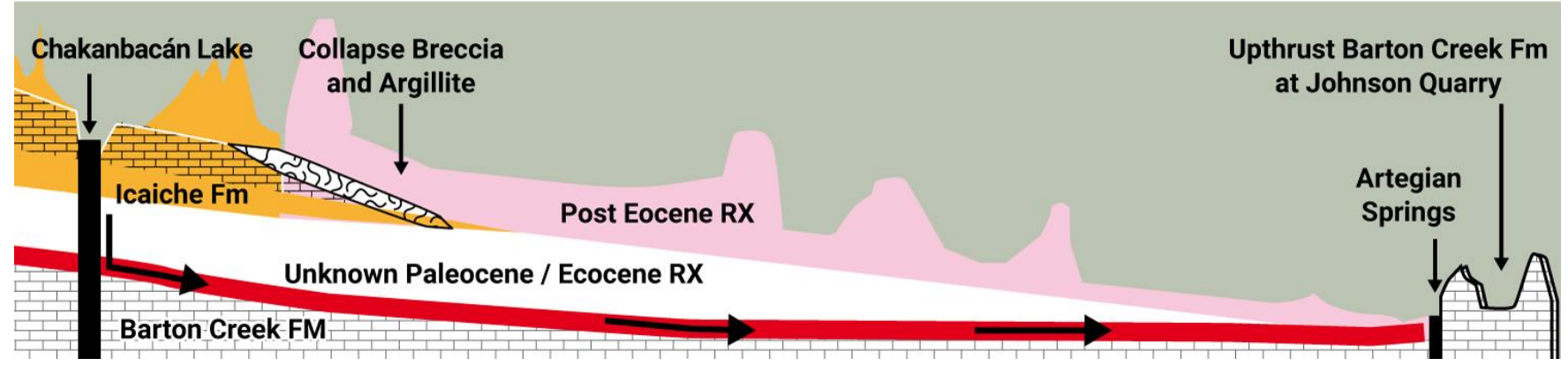

Figure 3 Schematic cross section of proposed Icaiche Formation aquifer. 
forested terrain. Highway excavations produced fresh exposures of highly soluble gypsum that $\mathrm{B}$ and $\mathrm{B}$ examined before those outcrops could dissolve and disappear in the wet climate of southern Campeche [where average annual rainfall, although variable, is normally about 1100-1600 mm/year (Dunning et al.,2012; Dunning et al., 2016)].

In fact, gypsum in the area rarely crops out except where it has been exposed by relatively recent excavation in road cuts and quarries. Those limitations may have caused $\mathrm{B}$ and $\mathrm{B}$ and subsequent investigators (Lopez Ramos, 1973; Weidie et al., 1985) to significantly underestimate the abundance of gypsum in the Icaiche Formation and hence in the EIR. Where newly exposed (Figure 4), the gypsum unit in the Icaiche Formation is up to 25-35 m thick (Perry et al., 2019). Using known gypsum outcrops and the gypsum quarries marked on the 2007 edition of the Servicio Geológico Mexicano geologic map of the Peninsula (henceforth SGM 2007) it is possible to outline an area, probably exceeding $10,000 \mathrm{Km}^{2}$, over which gypsum crops out in the EIR. This is the area indicated by shading in Figure 1 .
From a high point in south-central Campeche, the Icaiche Formation dips gently northward beneath younger rocks; and, whereas it is exposed extensively in Campeche state, it does not appear at the surface in northern Quintana Roo. In Yucatán state it crops out only in the southernmost corner (Perry et al., 2018 and Perry et al., 2019). Weathering of Icaiche gypsum releases sulfate that contaminates groundwater within the EIR; as demonstrated quantitatively by Wagner, 2009 and Perry et al., 2011.

Although no pre-Paleogene formations are shown in SGM 2007, a narrow band of Upper Cretaceous rocks, which is the stratigraphic equivalent of the Barton Creek Formation (BCF) of neighboring Belize, is present in southeastern Quintana Roo within a block uplifted in the RHFZ (Pope et al., 2005). These rocks are exposed in the Johnson limestone/dolomite quarry $\left(18.517^{\circ} \mathrm{N}\right.$, $88.484^{\circ} \mathrm{W}$ ) near the town of Juan Sarabia, Quintana Roo (Figure 1). The BCF is part of the Upper Cretaceous Yucatán Group (Viniegra-O., 1981; Peterson, 1983). Paleogeographic analysis by Viniegra-O. (1981) shows that the whole of the Cretaceous System of MY and adjacent Guate-

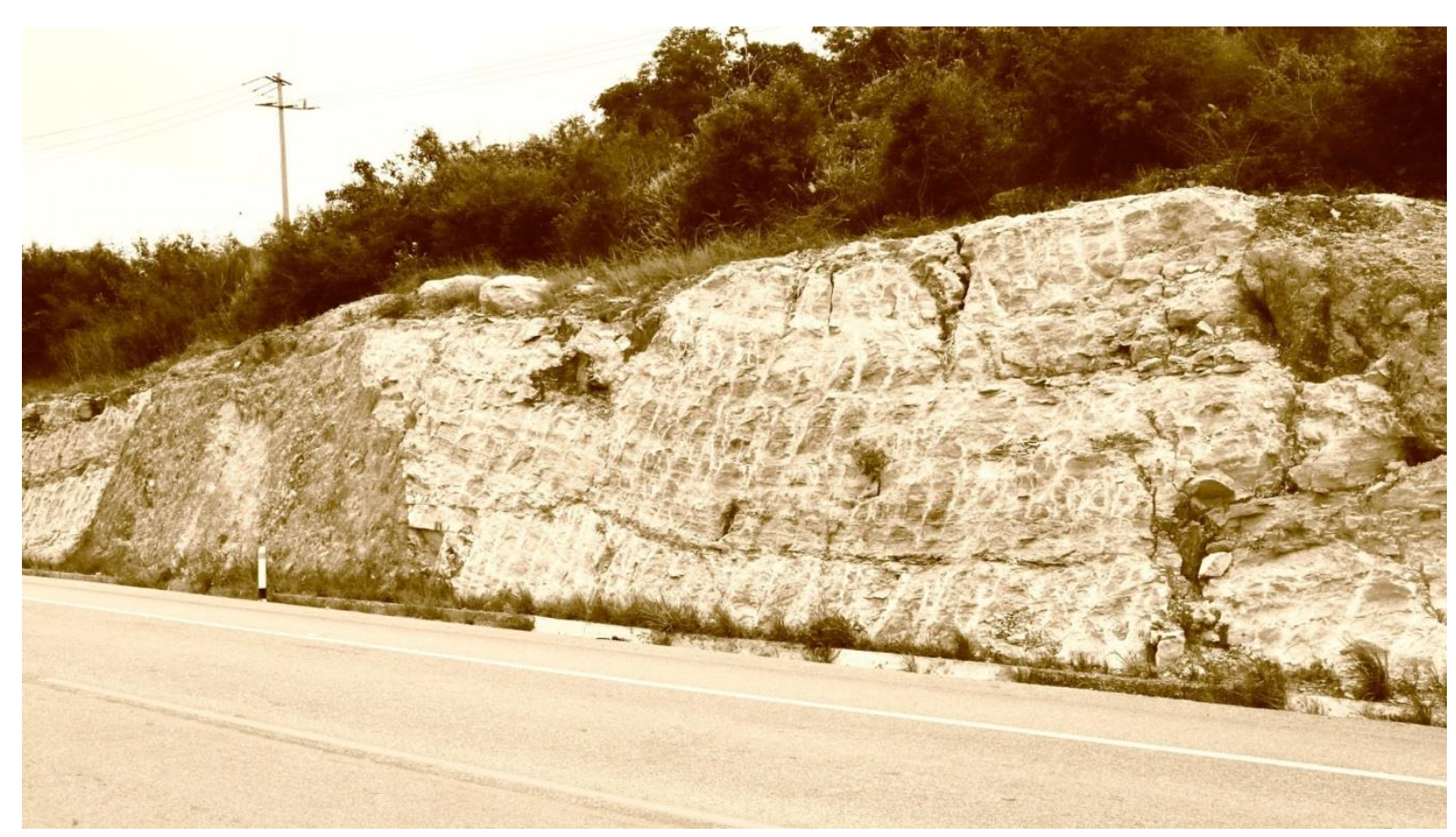

Figure 4 Outcrop of massively bedded gypsum of the laiche Formation along Mexican highway 186 (at $18.530^{\circ} \mathrm{N}, 89.576^{\circ} \mathrm{W}$ ) near Xpujil, Campeche. 
mala and Belize is comprised of a thick sequence of carbonates and evaporites that formed on a large contiguous shallow platform.

At Ramonal $\left(18.42^{\circ} \mathrm{N}, 88.53^{\circ} \mathrm{W}\right)$ on the western edge of the RHFZ (Figure 1) there is a small outcrop of deeply weathered BCF dolomite with iron oxide staining, calcite veins, and abundant solution cavities (Pope et al., 2005). The BCF is also present at several localities in Belize on the eastern side of the Rio Hondo (which here marks the Mexico-Belize border and flows within the RHFZ). In particular, the BCF is well exposed in Belize at the Albion Island quarry $\left(18.13^{\circ} \mathrm{N}, 88.70^{\circ} \mathrm{W}\right.$, labeled "Barton Creek" in Figure 1), about 48 km south of the Johnson quarry (Ocampo et al., 1996; King and Petruny, 2014).

The upper BCF surfaces in both the Johnson and Barton Creek quarries exhibit karst weathering features, and, at the well exposed Ramonal BCF outcrop, there is "extensive karst weathering with local relief of 3-10 $\mathrm{m}$ in the surface of a heavily recrystallized limestone with iron-oxide staining, caliche deposits, abundant vugs and travertine deposits" (Pope et al., 2005).

The Albion Formation disconformably overlies the karst erosion surface of the BCF at each of the three BCF outcrops mentioned. (Pope et al., 2005) It is a basal Paleogene ejecta blanket composed of fragments expelled from the 65 my Chicxulub bolide impact crater (Schulte et al., 2010). In addition to the outcrop at Ramonal where the Albion Formation overlies the BCF, Pope et al.,(2005) have described numerous other outcrops of the Albion Formation along Ucum-La Unión highway (which parallels the western edge of the RHFZ).

The formation is weakly consolidated, and the mineralogy, texture, and size of its components are remarkably diverse. Pope et al., 2005 give field and laboratory descriptions of several of the accessible and easily identifiable outcrops of the formation. Their description of the outcrops at Ramonal does not include the entire range of the lithology of the Albion Formation, but it of does demonstrate its heterogeneity.

At Ramonal, they report micritic limestone and dolomite cobbles and boulders up to $3 \mathrm{~m}$ in diameter that are supported by a matrix of calcite and dolomite silt. In thin section they report devitrified glass converted to clay with vesicles filled with carbonate matrix, limestone clasts containing foraminifera, and accretionary lapilli, all in a matrix of carbonate grains.

It is reasonable to infer that the $\mathrm{BCF}$ is present at depths of 4-20 m beneath the Albion Formation outcrops along the Ucum- La Unión highway. It is especially relevant to the present study and worth emphasis here that, where it is exposed in the Johnson quarry and at Ramonal, the BCF is a unit of relatively pure limestone/dolomite rock whose upper surface is thoroughly karstified. And, as noted above, at the beginning of the Paleogene that weathered surface was covered only by a thin layer of impact ejecta (the Albion Formation). Both the upper, weathered part of the BCF and perhaps parts of the weakly consolidated Albion Formation are likely to be quite permeable; hence, if extensive they would be expected to form a highly conductive aquifer.

\subsection{EAST COAST FAULTING AND THE RHFZ}

In addition to the rock units discussed above, the RHFZ (Figure 1) is also an essential component of the hydrologic system we think is responsible for deep movement of high-sulfate groundwater from the EIR into and through the eastern coastal plain. This fault zone is part of the prominent system of faults that extends in a broad band parallel to the Caribbean coast from northernmost Quintana Roo (where it is known as the Holbox Fracture Zone (Southworth, 1985; Tulacyzk et al.,1993)) southward beyond the Belize border. Many parallel fault traces appear as alignments on SGM 2007, and they are also present offshore as evidenced by the fault-bounded coasts of Cozumel Island and Chinchorro Bank (Rosencrantz, 1990). These are ancient faults, associated with the crustal movement involved in the formation of the Caribbean Basin (Rosencrantz, 1990; Gondwe et al., 2012). They are important components of the hydrologic system of MY (Tulaczyk et al., 1993; Bauer-Gottwein et al., 2011), and they have had a significant role in sculpting the MY Caribbean coast. 
As the name implies, the Rio Hondo river valley occupies the eponymous RHFZ as does Lake Bacalar to the north. These water bodies, which are directly connected, both contain high-sulfate water received from groundwater and from springs along the western escarpment of the fault. Before Pleistocene sea level rise opened the present Rio Hondo river mouth at Chetumal, these two bodies may have formed a continuous system draining to the sea through Bahia de la Ascension or Bahia del Espiritu Santo. Together they constitute the surface expression of a deeper flow system. Specifically, Guadalupe Velazquez and Eugene Perry (2012, unpublished) confirmed by direct measurement that a known sinkhole or cenote within Lake Bacalar is at least $45 \mathrm{~m}$ deep. Furthermore, Cenote Azul, which is within the Fault Zone and separated from Lake Bacalar by only a narrow strip of land, is $>64 \mathrm{~m}$ deep and contains a chemically homogeneous water column whose water is nearly saturated with respect to gypsum from top to bottom (Table 1) (Perry et al., 2002).

\section{Regional groundwater and surface water analyses and calculation of SI ${ }_{\text {gypsum }}$}

A study by Sánchez-Sánchez et al., (2016) contains chemical analyses and geographic coordinates of groundwater and surface water samples of southern Quintana Roo that greatly increase the regional hydrologic database. The focus of the Sánchez-Sánchez et al., (2016) paper is the use of factor analysis to distinguish families of water. We have extended their study by using their chemical analyses to determine the saturation indices (SI) of the sampled waters with respect to gypsum (Parkhurst, 1995). [SI $=\log (\mathrm{Q} / \mathrm{K})]$, where $\mathrm{Q}$ is the ion activity product of sulfate and calcium ions in a given solution, and $\mathrm{K}$ is the solubility product constant for gypsum.

Thus, an SI of zero corresponds to a water whose activity product $(\mathrm{Q})$ indicates precise saturation with gypsum. Note that calculation of SI requires activities (not concentrations) of calcium and sulfate ions. These activities can be determined from the Sánchez-Sánchez et al.,(2016) dataset because those authors have reported complete major element analyses for their samples, thus permitting us to determine activity coefficients of calcium and sulfate ions specific to each sample.

We have combined the data from Sánchez-Sánchez et al., (2016) with earlier results by Perry et al.,2002 and Perry et al., 2011 to produce both Table 1 and Figure 5 (the spatial representation of the geochemical data). As noted in section 2.1, gypsum of the Icaiche Formation crops out on the surface in roadcuts and quarries of the EIR over much of the shaded area of Figure 1. Not surprisingly, as can be seen from the figure, those water samples that are from wells or from springs in direct contact with Icaiche Formation gypsum have saturation indices that indicate nearly complete saturation, i.e. values near zero (ranging from +0.02 to -0.15 , with antilog values in Figure 5 between 1.05 and 0.71 respectively) and correspondingly high sulfate ion concentrations ranging from 31 to $36.5 \mathrm{meq} / \mathrm{l}$. These high values are plotted as relatively large circles in the left map (for $\mathrm{SI}_{\text {gypsum }}$ ) and center map (for sulfate concentration).

Samples from the area of gypsum outcrops in the EIR of southern Campeche (shaded area in figures 1 and 5) have relatively low but variable chloride ion concentrations that, in waters with high $\mathrm{SI}_{\text {gypsum }}$, could indicate release of pockets of halite and other highly soluble evaporite minerals trapped within armoring layers of weathering gypsum. In the case of three samples from the community of La Guadalupe, part of the chloride content may come from pollution by humans.

La Guadalupe is a remarkably poor community established adjacent to an outcrop of gypsum that contains a spring (which could have been a reason to site the village in this inappropriate spot). Water in the two hand-dug community wells is so contaminated by sulfate (a laxative) that CONAGUA (the national water commission) delivers potable water here by tank truck. Two of the La Guadalupe water samples in Table 1 come from the hand-dug wells within the village. 
Table 1. Location and ion content of groundwater and surface water from samples collected in Campeche and Quintana Roo.

\begin{tabular}{|c|c|c|c|c|c|c|c|}
\hline Sample* & Site & Long. & Lat. & $\mathrm{Cl}$ & $\mathrm{SO}_{4}$ & $\mathrm{SI}_{\text {gypsum }} * *$ & $100 \mathrm{SO}_{4} / \mathrm{Cl}$ \\
\hline O05 & $\begin{array}{l}\text { Jose María Morelos } \\
\text { (Cibali) }\end{array}$ & 89.285 & 17.886 & 2.43 & 1.29 & -1.899 & 53.20 \\
\hline $\mathrm{O} 23$ & La Unión & 88.870 & 17.897 & 0.76 & 26.02 & -0.379 & 3416.68 \\
\hline $\mathrm{O} 31$ & Arroyo Negro & 89.316 & 17.920 & 0.69 & 0.09 & -3.092 & 13.06 \\
\hline $\mathrm{O} 04$ & Lázaro Cárdenas \#2 & 89.232 & 17.957 & 1.66 & 0.69 & -2.137 & 41.28 \\
\hline $\mathrm{O} 22$ & Esteban Baca Calderón & 88.822 & 18.009 & 1.44 & 0.44 & -2.298 & 30.39 \\
\hline $\mathrm{O} 03$ & Santa Rosa & 89.195 & 18.013 & 2.31 & 0.83 & -2.159 & 36.00 \\
\hline $\mathrm{O} 02$ & Nuevo Veracruz & 89.175 & 18.050 & 1.10 & 3.96 & -1.423 & 359.54 \\
\hline $\mathrm{O} 35$ & José Narciso Rovirosa & 88.724 & 18.111 & 1.37 & 0.50 & -2.194 & 36.67 \\
\hline $\mathrm{O} 21$ & San Francisco Botas & 88.718 & 18.115 & 0.76 & 0.25 & -2.578 & 32.80 \\
\hline $\mathrm{O} 01$ & Dos Aguadas & 89.143 & 18.126 & 0.39 & 0.25 & -2.652 & 63.26 \\
\hline NIK & Cocoyol well & 88.694 & 18.163 & 1.00 & 15.71 & -0.45 & 1571.57 \\
\hline NIK & Cocoyol river & 88.683 & 18.166 & 0.55 & 19.26 & -0.33 & 3515.88 \\
\hline $\mathrm{O} 28$ & Tres Garantías & 88.983 & 18.193 & 1.68 & 1.08 & -2.101 & 64.39 \\
\hline $\mathrm{O} 10$ & Pucté & 88.670 & 18.232 & 1.04 & 0.15 & -2.662 & 13.96 \\
\hline O11 & Álvaro Obregón & 88.657 & 18.296 & 0.99 & 0.73 & -2.042 & 73.80 \\
\hline NIK & La Guadalupe spring & 89.484 & 18.328 & 9.93 & 32.41 & -0.07 & 326.21 \\
\hline NIK & $\begin{array}{l}\text { La Guadalupe upper } \\
\text { well }\end{array}$ & 89.480 & 18.331 & 11.92 & 31.00 & -0.04 & 260.15 \\
\hline NIK & $\begin{array}{l}\text { La Guadalupe lower } \\
\text { well }\end{array}$ & 89.481 & 18.332 & 16.29 & 36.46 & 0.02 & 223.87 \\
\hline NIK & Rancho del Toro spring & 88.596 & 18.348 & 0.91 & 15.12 & -0.49 & 1664.42 \\
\hline NIK & Rancho del Toro well & 88.596 & 18.348 & 0.91 & 14.66 & -0.5 & 1607.41 \\
\hline $\mathrm{O} 17$ & San José de la Montaña & 89.010 & 18.371 & 2.26 & 1.46 & -1.875 & 64.58 \\
\hline $\mathrm{O} 20$ & Allende & 88.553 & 18.385 & 1.27 & 13.53 & -0.710 & 1066.01 \\
\hline NIK & Acapulquito Spring & 88.531 & 18.432 & 1.14 & 19.73 & -0.35 & 1737.15 \\
\hline NIK & Palmar river & 88.526 & 18.440 & 0.87 & 16.85 & -0.41 & 1928.01 \\
\hline NIK & Palmar spring & 88.528 & 18.440 & 1.09 & 20.57 & -0.33 & 1880.82 \\
\hline O16 & Caobas & 89.101 & 18.442 & 1.89 & 36.43 & -0.149 & 1927.62 \\
\hline NIK & $\begin{array}{l}20 \text { de Noviembre } \\
\text { spring }\end{array}$ & 89.307 & 18.451 & 7.95 & 32.50 & -0.03 & 408.65 \\
\hline $\mathrm{O} 27$ & Nicolás Bravo & 88.931 & 18.463 & 1.70 & 1.46 & -1.842 & 85.53 \\
\hline $\mathrm{O} 12$ & Sacxan & 88.522 & 18.464 & 1.83 & 19.78 & -0.537 & 1078.62 \\
\hline O09 & Francisco & 88.844 & 18.477 & 2.09 & 0.21 & -2.627 & 9.97 \\
\hline O18 & Ñachi Cocom & 88.750 & 18.480 & 0.96 & 5.41 & -1.172 & 564.36 \\
\hline O19 & Jesús González Ortega & 88.674 & 18.487 & 1.78 & 14.57 & -0.652 & 820.00 \\
\hline $\mathrm{O} 34$ & Ucum & 88.522 & 18.504 & 2.19 & 8.24 & -0.922 & 376.51 \\
\hline O06 & Sergio Butrón Casas & 88.568 & 18.510 & 4.09 & 4.37 & -1.492 & 106.88 \\
\hline O15 & Calderitas & 88.263 & 18.554 & 5.42 & 41.64 & -0.116 & 768.75 \\
\hline
\end{tabular}

*Samples with labels beginning with B, F, and O are from Sánchez-Sánchez et al., 2016. Samples with labels beginning with NIK are from Wagner, 2009 and Perry et al., 2011 . Samples with labels beginning with PVM are from Perry et al, 2002. *"Defined in text. 
Table 1. (Continuation) Location and ion content of groundwater and surface water from samples collected in Campeche and Quintana Roo.

\begin{tabular}{|c|c|c|c|c|c|c|c|}
\hline Sample* & Site & Long. & Lat. & $\mathrm{Cl}$ & $\mathrm{SO}_{4}$ & $\mathrm{SI}_{\mathrm{gypsum}} * *$ & $100 \mathrm{SO}_{4} / \mathrm{Cl}$ \\
\hline $\mathrm{O} 13$ & Xul-Ha & 88.489 & 18.571 & 3.92 & 15.61 & -0.686 & 398.20 \\
\hline NIK & Zoh Laguna lagoon & 89.418 & 18.588 & 0.23 & 0.03 & -3.85 & 12.92 \\
\hline NIK & Zoh Laguna well & 89.416 & 18.597 & 7.90 & 31.49 & -0.04 & 398.62 \\
\hline $\mathrm{O} 08$ & Morocoy & 88.811 & 18.599 & 2.43 & 2.91 & -1.556 & 120.14 \\
\hline PVM & Cenote Azul (avg) & 88.410 & 18.650 & 1.20 & 25.05 & -0.22 & 2087.50 \\
\hline NIK & Lake Bacalar & 88.405 & 18.657 & 2.98 & 23.67 & -0.29 & 794.80 \\
\hline $\mathrm{O} 33$ & San Pedro Peralta & 88.859 & 18.696 & 2.62 & 0.60 & -2.228 & 22.74 \\
\hline $\mathrm{O} 07$ & $\begin{array}{l}\text { Lázaro Cárdenas } \\
\text { Segundo }\end{array}$ & 88.846 & 18.720 & 1.44 & 0.67 & -2.182 & 46.31 \\
\hline B26 & Bacalar Pozo 2 & 88.439 & 18.729 & 3.42 & 1.24 & -1.893 & 36.20 \\
\hline NIK & Bacalar well & 88.440 & 18.730 & 4.47 & 5.42 & & 121.29 \\
\hline B20 & Carretera Reforma & 88.440 & 18.730 & 4.43 & 12.91 & -1.023 & 291.44 \\
\hline B05 & La Ceiba & 88.500 & 18.796 & 3.61 & 3.96 & -1.368 & 109.55 \\
\hline B02 & Reforma & 88.573 & 18.813 & 1.44 & 1.06 & -1.957 & 73.80 \\
\hline B06 & Miguel Hidalgo & 88.343 & 18.827 & 1.95 & 2.08 & -1.729 & 106.96 \\
\hline B04 & Altos de Sevilla & 88.681 & 18.854 & 3.05 & 0.73 & -2.116 & 23.92 \\
\hline B25 & Buenavista & 88.237 & 18.889 & 44.51 & 29.15 & -0.508 & 65.48 \\
\hline B27 & $\begin{array}{l}\text { David Gustavo } \\
\text { Gutiérrez }\end{array}$ & 88.701 & 18.896 & 5.75 & 0.20 & -2.75 & 3.44 \\
\hline B08 & Blanca Flor & 88.502 & 18.926 & 0.99 & 0.42 & -2.427 & 42.17 \\
\hline B07 & Maya Balam & 88.402 & 18.936 & 2.76 & 7.70 & -1.055 & 278.63 \\
\hline B18 & Pedro Antonio Santos & 88.166 & 18.958 & 31.51 & 11.87 & -0.886 & 37.66 \\
\hline B17 & Lázaro Cárdenas & 89.162 & 18.971 & 1.55 & 0.54 & -2.269 & 34.89 \\
\hline B09 & La Buena Fe & 88.510 & 18.982 & 5.56 & 3.12 & -1.528 & 56.19 \\
\hline B10 & Nuevo Jerusalén & 88.569 & 18.996 & 2.76 & 2.29 & -1.734 & 82.84 \\
\hline B22 & Los Limones & 88.110 & 19.022 & 17.15 & 2.50 & -1.591 & 14.57 \\
\hline B23 & Chacchoben & 88.176 & 19.029 & 2.93 & 0.60 & -2.286 & 20.58 \\
\hline B16 & Manuel Ávila Camacho & 88.423 & 19.041 & 9.39 & 5.41 & -1.305 & 57.62 \\
\hline B15 & Los Divorciados & 88.457 & 19.074 & 3.86 & 5.00 & -1.34 & 129.29 \\
\hline PVM & Nohbec & 88.170 & 19.140 & 1.13 & 1.08 & -1.99 & 95.58 \\
\hline B24 & Noh Bec & 88.168 & 19.142 & 0.65 & 0.37 & -2.522 & 57.76 \\
\hline F04 & Andrés Quintana Roo & 88.103 & 19.162 & 4.93 & 3.23 & -1.297 & 65.52 \\
\hline F05 & Polinkín & 88.171 & 19.175 & 2.06 & 1.52 & -1.772 & 73.80 \\
\hline F06 & Petcacab & 88.225 & 19.291 & 6.48 & 1.79 & -1.81 & 27.62 \\
\hline F03 & X Zazil Sur & 88.080 & 19.392 & 3.02 & 1.21 & -1.954 & 40.04 \\
\hline F02 & Uh May & 88.048 & 19.417 & 2.68 & 1.46 & -1.794 & 54.32 \\
\hline PVM & Ocom & 88.100 & 19.470 & 4.96 & 4.83 & & 97.38 \\
\hline F01 & Chankah Veracruz & 87.994 & 19.495 & 1.79 & 1.32 & -2.082 & 73.45 \\
\hline
\end{tabular}

*Samples with labels beginning with B, F, and O are from Sánchez-Sánchez et al., 2016. Samples with labels beginning with NIK are from Wagner, 2009 and Perry et al., 2011 . Samples with labels beginning with PVM are from Perry et al, 2002. **Defined in text. 
The third sample is from the spring adjacent to the town. Each of these samples has an $\mathrm{SI}_{\text {gypsum }}$ indicating saturation with respect to gypsum $(+.02$ to -0.07). Both wells have nitrate concentrations indicating significant anthropogenic pollution by organic matter, and all have relatively high chloride contents, which could come from dissolution of evaporite minerals or from anthropogenic sources. Despite this contamination, we confidently include these as valid samples here for two reasons: 1) the spring sample is in direct contact with gypsum, and 2) the SI $I_{\text {gypsum }}$ values of each sample indicate that the sulfate concentration of each sample is controlled by equilibrium with gypsum.

A few samples in the area of gypsum outcrops have quite low sulfate ion concentrations and negative gypsum saturation indices, indicating strong undersaturation. These are from known shallow sources fed by rain; and, typically, they are isolated from dissolving gypsum by layers of impermeable surficial clay. As we noted in section 1.1, the Maya of the EIR used natural and anthropogenically modified shallow water bodies like these as primary water sources during their peak period of occupation of the EIR a few centuries before and after 100 CE.

\section{Regional patterns in water chemistry}

East of the high-sulfate waters of the EIR there are two distinct zones outlined by their qualitatively different groundwater chemistry (Figure 5). Nearest to the EIR is a zone, or gap, approximately $50 \mathrm{~km}$ wide, trending in the direction of the RHFZ, in which groundwater has relatively low concentrations of chloride and sulfate ions and corresponding gypsum saturation indices ranging as low as -3.1.

Within the gap between the high-sulfate water of the EIR and the RHFZ, there are surface channels up to several meters deep that were established and are maintained by recurring episodic overland flow from storms. We can assert from a reconnaissance study by Leal-Bautista, et al., (2017) that these are not responsible for transporting high sulfate to the RHFZ because ephemeral lakes and ponds that are present in their channels contain fresh water of low ion conductivity. The most remarkable feature clearly demarcated in Figure 5 is the relatively narrow band containing high-sulfate water within and adjacent to the RHFZ and lying of the zone of relatively ion-free water. This band is comprised of wells, flowing springs, and cenotes with gypsum saturation indices ranging from -0.22 for water from Cenote Azul to -0.5 for a well (Rancho del Toro) $200 \mathrm{~m}$ from the Rio Hondo (Figure 5). Water samples from the river itself and from Laguna Bacalar also have near-saturation indices of -0.33 and -0.29 respectively. Allowing for some mixing with surface water and shallow groundwater, these results strongly suggest a direct connection between high-sulfate groundwater generated by gypsum dissolution in the EIR and the water that appears in the RHFZ, presumably from a higher elevation recharge zone to the west.

A cautionary note is that gypsum probably is also present in the EIR south of the Mexican border, and water with high sulfate concentration may be present in water of the Rio Hondo flowing north into Mexico from Belize. However, such river water entering from outside the study area would represent only a complimentary sulfate source (and is quite probably an extension into Belize and Guatemala of the system we describe). Evidence for a major sulfate source in the Mexican EIR is that the high-sulfate springs in the Rio Hondo valley are under a strong positive hydrostatic head. For example, Acapulquito Spring Table 1) has an elevation at the park pool of 15 masl, but the source spring can be traced to a small arroyo that heads up at about $30 \mathrm{~m}$ (Google Earth, accessed 9 September, 2020). (We note that " $E$ " in the acronym "EIR" stands for "Elevated" and implies that this is a likely recharge area.

\section{A proposed deep aquifer that transports high-sulfate groundwater to the coast from the EIR}

We have demonstrated that, in a sparsely populated part of MY, namely, in southern Campeche state and southwestern Quintana Roo, there exists a highland region of distinctive high-sulfate ground- 
water recharge produced by dissolution of gypsum (the Icaiche recharge zone). Although the detailed geologic structure and subsurface stratigraphy of the area are incompletely known, the near-surface rocks are nearly flat-lying. We have further established that $50 \mathrm{~km}$ away, an adjacent lowland region exists that is a zone of high-sulfate groundwater discharge (the RHFZ). The composition of groundwater in the two regions is strikingly similar as can be seen by comparison of water in the two regions documented in Table 1 and illustrated in Figure 5. Rather than asking whether the two groundwater systems are directly connected, we think it more reasonable to ask: "How can they not be connected?" Rocks in the right stratigraphic position and with reasonable permeability to form a deep aquifer connecting the Icaiche recharge zone and the RHFZ discharge zone do exist. These are the karstified upper Cretaceous rocks of the BCF and the overlying weakly consolidated K-Pg deposits of the Albion Formation exposed at both the Johnson and Albion quarries and along the Ucum-La Unión highway. There is no direct evidence at present to indicate that either or both of these formations continue westward and thus directly underly the Icaiche Formation in the zone of recharge. But, overlying near-horizontal Paleogene rocks do persist westward into the EIR, so there is no stratigraphic evidence against such a projection.

Accordingly, we propose here, as a hypothesis to be tested, that a composite aquifer consisting of the Albion Formation and the upper, permeable part of the BCF continue west and that together they form a deep aquifer carrying high-sulfate water, generated by dissolution of Icaiche Formation gypsum, eastward and discharge this water into the RHFZ. The suggested stratigraphy is shown in Figure 2, and a schematic of the proposed aquifer system is shown in Figure 3.

Our model, is consistent with the following observations and inferences: 1) Gypsum-saturated, sulfate-rich groundwater is present throughout that part of the EIR covered by Icaiche Formation rocks containing abundant gypsum, specifically in the shaded area of Figures 1 and 5. Given that the estimated annual rainfall in the region is about $1100-1600 \mathrm{~mm} /$ year it follows that the amount of recharge must be large. Yet, referring specifically
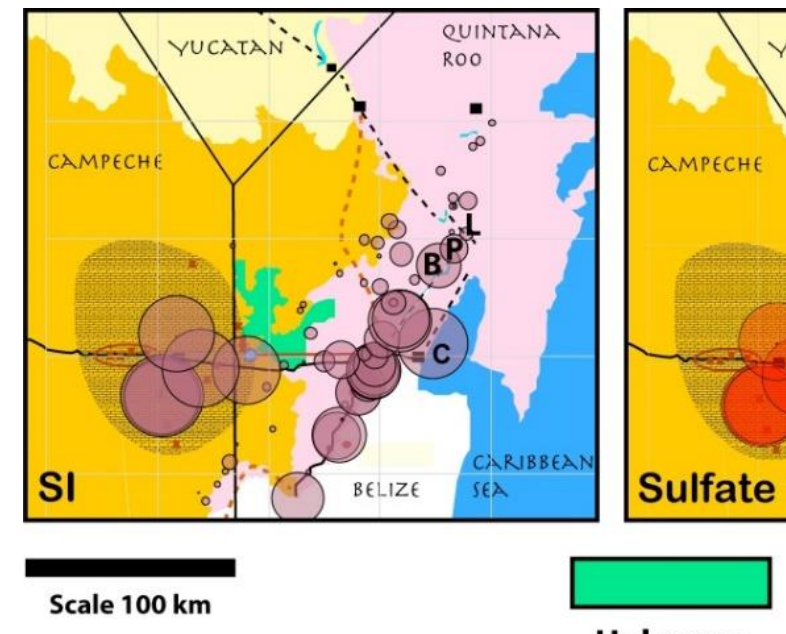

Scale $100 \mathrm{~km}$
Holocene

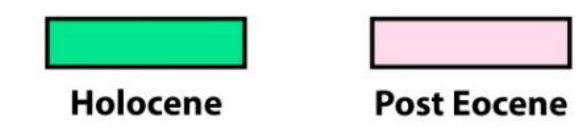

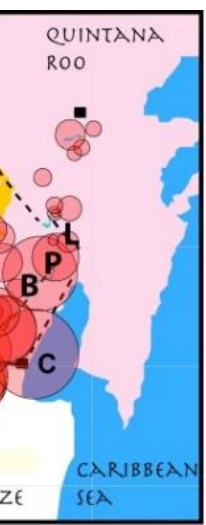

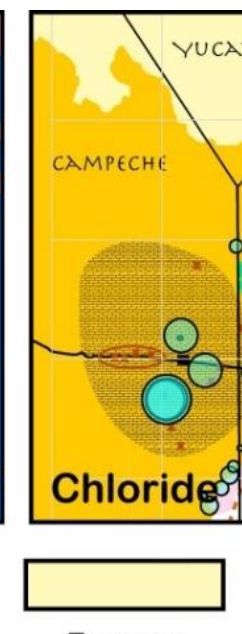

Eocene

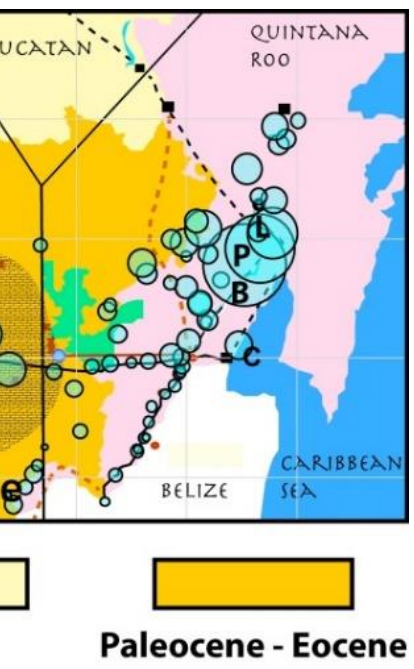

Figure 5 Analyses of groundwater and surface waters of southeastern MY listed in Table 1. Chemical data are superimposed on a simplified version of the map of Figure 1. For sulfate and chloride, circle size is proportional to concentration. On the leftmost map, circle size is proportional to the antilog of the gypsum Saturation Index $\left(\mathrm{SI}_{\text {gypsum }}\right)$; thus, large circles indicate near-saturation with respect to gypsum. Comparing the three figures, there is an obvious positive correlation of sulfate concentration with $\mathrm{SI}_{\mathrm{gyps} u m}$ and a low or negative correlation with chloride (right hand figure). (It is important to note that the circles refer specifically to the chemistry of the water at the point marked by their center. Higher or lower values may, and probably do, exist within the map areas of the circles.) Samples labelled C, B L, and P are identified in the text. 
to the eastern edge of the EIR, for which we have data, there is no evident continuous path by which this groundwater is discharged to the ocean. Surface water and shallow groundwater in the $50 \mathrm{~km}$ "gap area" west of the RHFZ is characterized by low sulfate content. 2) Water nearly saturated with respect to gypsum and containing exceptionally high concentrations of sulfate enters the RHFZ from an un-recognized source and is discharged by the Rio Hondo and by flowing springs in a narrow zone whose axis is the NNE-SSW Fault Zone, which is separated by $50 \mathrm{~km}$ from the nearest known high-sulfate groundwater. 3) An uplifted fault block of the $\mathrm{BCF}$ limestone/dolomite is brought to the surface in the RHFZ along the Mexico-Belize border between the Johnson quarry in Mexico and the Albion quarry in Belize (Figure 1). 4) In the late Cretaceous, even before emplacement of the $\mathrm{K} / \mathrm{Pg}$ Albion Formation and any subsequent rocks, the uppermost part of the BCF had been altered by strong weathering to produce a karst surface. 5) It is reasonable to project the $\mathrm{BCF}$ westward beneath the younger formations to a position beneath the Icaiche Formation, where its weathered upper surface could serve as an effective aquifer for transport of high-sulfate water to the RHFZ on the east coast. One apparent anomaly in Figure 5 is the high SI of a near-coastal water from a well in the Chetumal suburb of Calderitas (labelled "C" in Figure 5). That water can be readily explained by our model if, as is likely, the linear coast north of Chetumal is actually a fault parallel to the main RHFZ and the other faults that define much of the east coastline as suggested in Figure 1). It is reasonable to expect that this fault also taps water from the presumptive Barton Creek aquifer.

\section{Complications and Caveats}

Factors complicating the deep aquifer hypothesis are: 1) Possible faulting in the BCF whose geology in Belize and Guatemala is known to be complex (King et al., 2003; King et al., 2004; King and Petruny, 2014). 2) Probable facies changes and permeability variation in the Miocene-Pliocene
Carrillo Puerto Formation and underlying eastern coastal Miocene formations as shown schematically in the stratigraphic column of SGM 2007 and discussed in Perry et al., (2019). 3) Variable quantity and chemistry of regional surface water and shallow groundwater input sources that could mix with and generally dilute the putative deep groundwater from the EIR. 4) Penetration of a saline intrusion into the northernmost part of the RHFZ (shown by high chloride concentration and correspondingly lower SI in water of the three northernmost wells along the RHFZ projection. Of these interesting uncertainties, the data set presented here in Table 1 is only useful in addressing the fourth one: what happens to groundwater flowing through the RHFZ as it moves north into the extensive, complex and poorly understood area south and east of Lake Chichancanab $\left(19.88^{\circ} \mathrm{N}\right.$, $88.77^{\circ} \mathrm{W}$ ) in the eastern part of Quintana Roo. That is the area where the Ticul Fault and the RHFZ intersect (Perry et al., 2019).

Three samples presented in Table 1 have chloride values high enough to confirm that they have definitely mixed with water of marine origin. These are: Buenavista $\left(18.889^{\circ} \mathrm{N}, 88.237^{\circ} \mathrm{W}\right)$, Pedro Antonio Santos $\left(18.958^{\circ} \mathrm{N}, 18.958^{\circ} \mathrm{W}\right)$, and Los Limones $\left(19.022^{\circ} \mathrm{N}, 88.110^{\circ} \mathrm{W}\right)$. They are marked B, P, and L respectively in Figure 5 . The most noteworthy of these samples is from Buenavista, with a high sulfate concentration and SIgypsum (29.15meq/1 and -0.51 respectively) and a chloride concentration of $44.51 \mathrm{meq} / \mathrm{l}$. Thus, along with sulfate and SI values typical of the RHFZ, the Buenavista water has a chloride ion concentration that is $8 \%$ of the chloride concentration of seawater. It also has comparably high concentrations of sodium and magnesium (Sánchez-Sánchez et al., 2016). This amount of chloride in water from a municipal well is remarkable. Among the large number of wells (including those in coastal areas) in the MY used to obtain potable water that were sampled by Perry et al., 2002, no similar value is reported.

Below a thick freshwater lens, deep east coast cenotes do actually have even much higher chlo- 
ride concentrations than water from Buenavista. For example, in a cenote within the Calica quarry, $7 \mathrm{~km}$ from the Caribbean coast in northern Quintana Roo, Bianca Pedersen (2007, unpublished $\mathrm{PhD}$ thesis) reported that below a sharp interface separating fresh and saline water and at $14 \mathrm{~m}$ depth, chloride concentration increases rapidly, reaching an approximate seawater value of $400 \mathrm{meq} / \mathrm{l}$ at about $18 \mathrm{~m}$ depth. That profile makes it seem likely that a marine saline intrusion is present beneath the Buenavista well and that the well is drawing water from near the depth of the saline interface. That interpretation is supported by unpublished well logs provided by Joan Sánchez-Sánchez (Written Communication, 25 September, 2020). Those logs report $22.3 \mathrm{meq} / \mathrm{l}$ chloride in 2000 and $36.8 \mathrm{mq} / \mathrm{l}$ in 2009. This regular increase in chloride concentration with time suggests that a saline interface has progressively invaded the well over time, either by over-pumping of the well and consequent upconing or by a regional upward migration of the interface. We conclude that at Buenavista, significant mixing occurs between a marine saline intrusion and water flowing northward through the RHFZ.

Los Limones is the farthest north of the three chloride-rich cenotes in the northern RHFZ extension. It has the lowest sulfate and chloride concentrations of the three samples. Its $2.5 \mathrm{meq} / \mathrm{l}$ sulfate concentration is unremarkable, but its $17.15 \mathrm{meq} / \mathrm{l}$ chloride concentration is five times the average chloride concentration of samples in Table 1. Pedro Antonio Solis is located between Los Limones and Buenavista, and, among the three samples it is intermediate in sulfate, SI, and chloride values. The influence of sulfate derived from gypsum is obviously attenuated moving north from Buenavista. Chloride attenuation is also occurring perhaps as a result of increased fresh water input from the Ticul Fault and the northern fresh water lens.

Because groundwater from Buenavista is so unusual, we insert here for reference some observations whose significance we are unable to assess. Buenavista, which lies on a sharp bend near the northern end of Lake Bacalar, is $24 \mathrm{~km}$ south of Lake Noh Bec, the lake through which the exten- sion of the Ticul Fault is projected on the SGM 2007 map. The bent arms of both Lake Noh Bec and Lake Bacalar are approximately $5 \mathrm{~km}$ long. After this $5 \mathrm{~km}$ offset, the southeast arm of each lake bends back to parallel the direction of its western arm. Thus, the two lakes zigzag in parallel. The SGM 2007 map shows the bend in Lake Noh Bec as an offset on the Ticul Fault. If, as implied, the bend in Lake Noh Bec marks a fault, it looks as though Lake Bacalar may have been displaced in parallel, suggesting faulting contemporaneous with or subsequent to deposition of the Miocene-Pliocene Carrillo Puerto Formation.

\section{Independent Support}

Two quite different and independent recent observations are consistent with the existence of the deep aquifer proposed here. One is the recent catastrophic draining of a lake precisely where we have suggested that recharge of the proposed aquifer takes place. The second recent observation of possible relevance is the discovery of evidence for a large submarine discharge off the Caribbean coast of Quintana Roo.

\subsection{LAKE GHAKANBAGÁN: POSSIBLE SITE OF REGHARGE AND AGTIVE POLJE}

Lake Chakanbacán $\left(18.293^{\circ} \mathrm{N}, \quad 89.084^{\circ} \mathrm{W}\right), \quad$ a remote lake on the eastern border of the region of gypsum outcrops of the Icaiche Formation (Figure 1) drained suddenly during the week of August 20, 2018 (Leal-Bautista, et al., 2021). This lake, which has gypsum cropping out on its bank, is part of a NNE-SSW trending line of lakes and aguadas (swamps) about $8.5 \mathrm{~km}$ long that marks the extreme eastern edge of the Icaiche gypsum outcrops in southeastern Campeche. This alignment of surface depressions is easily discernable in Google Earth and closely matches the orientation of the RHFZ and numerous other regional faults. That suggests that Lake Chakanbacán may be part of a fracture system acting as a recharge zone for our proposed deep aquifer as is shown schematically in Figure 3. 
Lake Chakanbacán is located immediately west of the depression formed by the connected Nuevo Becak and Morocoy poljes (the composite geomorphic feature marked "Polje" in Figure 1). Perry et al.,2018; and Perry et al., (2019) have provided evidence that poljes of the EIR are collapse features produced by dissolution of gypsum of the Icaiche Formation. It is likely that the hydrologic system that includes Laguna Chakanbacán is responsible for subsurface erosion of gypsum followed by collapse and leading to continuing active expansion westward of poljes Nuevo Becak and Morocoy, as we have suggested schematically in Figure 3. A field report on the sudden drainage of Lake Chakanbacán and the possible significance of that event are presented in a companion to this paper (Leal et al., 2021).

\subsection{THE PROPOSED DEEP AQUIFER AS THE SOURGE OF A GARIBBEAN SUBMARINE DISGHARGE}

Our proposed deep aquifer system discharging along the Caribbean coast in southern Quintana Roo may resolve a question raised by salinity measurements of sea water along that coast. Carrillo et al., (2016) have reported an unexpectedly large input of fresh water into the ocean along the east coast of Quintana Roo, and they suggest a discharge on the order of $600 \mathrm{~m}^{3} / \mathrm{sec}$ in the vicinity of Bahia de la Ascension.

It is worth noting that the present mouth of the Rio Hondo, near Chetumal, is modern and that with a Pleistocene sea level $100 \mathrm{~m}$ below the current level, it is likely that, in the past, the Rio Hondo flowed northward underground to the Bahia through the RHFZ much like the discharge that currently occurs through the Ticul Fault in northwestern Yucatán state (Perry et al., 1995; Perry et al.,2002; Perez-Ceballos et al., 2012). Our model for draining the eastern EIR suggests that considerable subsurface discharge to the ocean may still occur through the RHFZ.

\section{Significance}

What is the regional significance of a possible deep aquifer containing sulfate-contaminated ground- water? Several factors may be relevant: 1) A human population wave, stimulated by tourism, is moving southward from Cancun and may soon stress the known exploitable supply of potable water on the Caribbean coast and in the adjacent EIR. Preparing for this influx will require better hydrologic information about the area than currently exists.

2) In contrast to Cancun and other populous parts of northeast Quintana Roo, it may be that the presence of an aquitard will isolate groundwater in the proposed deep, high-sulfate aquifer supplying Lake Bacalar and Cenote Azul and protect water in these recreation spots from contamination (or, conversely, it could produce greater contamination if the deep aquifer were selected as a prime waste disposal site). 3) A major objective of the Caribbean hydrographic study by Carrillo et al.,(2016) was to better understand marine conditions stressing corals in the largest coral reef system in the Atlantic Ocean. If a substantial part of the submarine discharge they discovered comes from the deep aquifer proposed here, then protecting that aquifer from pollution by sewage injection could be important to preservation of corals. 4) The Maya spent millennia learning how to thrive with the complex hydrologic systems of the EIR and the rest of the Peninsula. They persisted by developing sophisticated rainwater harvesting techniques Perry et al.,(2019). Archeologists and others are working to understand how the Maya civilization interacted with climate dynamics and how this might help a modern burgeoning population to effectively respond to climate change. Ultimately, the Maya abandoned the EIR, a region in which they had coped with extreme hydrologic challenges for many generations. Learning more about regional hydrology may help understand why they left.

\section{Conclusions}

We present and evaluate data suggesting that a previously unrecognized deep aquifer exists in a sparsely settled but developing part of southern Quintana Roo and adjacent southern Campeche. Evidence for this aquifer is indirect, derived 
from a study of groundwater geochemical data. Confirmation will require obtaining much more detailed and focused geochemical information than we have been able to present. However, real understanding of the hydrogeology of the region is possible only as part of an integrated geoscience program that begins with a coordinated mapping of regional stratigraphy and structure that extends into Belize and Guatemala. Such a project would also require comprehensive geophysical study, followed by drilling. Strong current and accelerating political and economic pressure to develop the region justifies such a study.

\section{Acknowledgements}

This is the second part of a study of the hydrogeology and aqueous geochemistry of the southeastern Mexican Yucatán Peninsula. This part focuses on a proposed deep aquifer in southeastern Campeche and southern Quintana Roo. We acknowledge institutional help from the Mexican National Water Commission (CONAGUA), especially from M en I. Jose Luis Acosta Rodríguez, Director Técnico of CONAGUA in Yucatán, and Ing. Ivan Gamboa Rosas Secretario Tecnico at CONAGUA- Quintana Roo. Dr. Liliana Lefticariu calculated saturation indices in Table 1 using the Geochemist's Workbench $\odot$. We are grateful for help in the field by Dr. Eduardo Cejudo (Centro de Investigación Científica de Yucatán), and we gratefully acknowledge valuable constructive criticism by Nicholas Dunning and David King, Jr. King also shared with us his extensive knowledge of related aspects of the geology across the borders with Belize and Guatemala. Although we had hoped to produce a joint paper on the hydrogeology of southeastern Mexico and northern Belize with Sheryl Luzzadder-Beach and Timothy Beach, that proved unfeasible because of uncertain correlation of geologic formations across the Mexico-Belize border. We thank Luzzadder-Beach and Beach for valuable dialog, and we hope to contribute in the future to a broad regional hydrogeologic study across national boundaries that will include relevant parts of southern Mexican Yucatán, northern Belize and northern Guatemala. Simon Ritter and an anonymous reviewer provided constructive criticism. In particular, Ritter encouraged us to explore additional interesting correlations in the data. This study received support from the Centro de Investigación Científica de Yucatán. We take responsibility for any errors in this manuscript.

\section{References}

Back, W., Hanshaw, B.B., 1970, Comparison of chemical hydrogeology of the carbonate peninsulas of Florida and Yucatan: Journal of Hydrology, 10(4), 330-368. https://doi. org/10.1016/0022-1694(70)90222-2

Back, W., Hanshaw, B.B., Pyle, T.E., Plummer, L.N., and Weidie, A.E., 1979, Geochemical Significance of Groundwater Discharge and Carbonate Solution to the Formation of Caleta Xel Ha, Quintana Roo, Mexico: Water Resources Research, 15(6),1521-1535. https://doi.org/10.1029/WR015i006p01521

Back, W., Hanshaw B.B., Herman, J.S., Van Driel, J.N., 1986, Differential dissolution of a Pleistocene reef in the ground-water mixing zone of coastal Yucatan, Mexico: Geology, 14(2), 137-140. https://doi. org/10.1130/0091-7613(1986)14<137:DDO $\mathrm{APR}>2.0 . \mathrm{CO} ; 2$

Bauer-Gottwein, P., Gondwe, R.N., Charvet G., Marín, L.E., Rebolledo-Vieyra M., Merediz-Alonso G., 2011, Review: The Yucatán Peninsula karst aquifer, Mexico: Hydrogeology Journal 19, 507-524. https:// doi.org/10.1007/s10040-010-0699-5

Beach, T.P., Luzzadder-Beach, S., Cook, D., Dunning, N., Kennett, D.J., Krause, S., Terry, R., Trein, D., Valdez, F., 2015, Ancient Maya impacts on the Earth's surface: An Early Anthropocene analog: Quaternary Science Reviews, 124, 1-30. https://doi. org/10.1016/j.quascirev.2015.05.028 
Butterlin, J., Bonet, F., 1960, Información básica para la interpretación geohidrológica de la península de Yucatán: México D.F., México, Reporte de la Secretaría de Recursos Hidráulicos, 32 p.

Carrillo, L., Johns, E.M., Smith, R.H., Lamkin J.T., Largier J.L., 2016, Pathways and hydrography in the Mesoamerican Barrier Reef System Part 2: Water masses and thermohaline structure: Continental Shelf Research 120, 41-58. https://doi. org/10.1016/j.csr.2016.03.014

Domínguez, M. delR., Folan, W.J., 1996, Calakmul, México: Aguadas, bajos, precipitación y asentamiento en el Petén Campechano, in Laporte, J.P., Escobedo, H. (eds), IX Simposio de Investigaciones Arqueológicas en Guatemala, Nacional de Arqueología y Etnología: Guatemala, Guatemala, Ministerio de Cultura y Deportes, 147-173.

Dunning, N.P., Beach, T.P., Luzzadder-Beach, S., 2012, Kax and kol: Collapse and resilience in lowland Maya civilization: Proceedings of National Academy of Sciences, 109 (10), 3652-3657. https://doi.org/10.1073/ pnas. 1114838109

Dunning N.P., Brewer J., Beach T., Luzzadder Beach S., Scarborough V., 2016, Ancient Water Collection and Storage in the Elevated Interior Region of the Maya Lowlands, in The $81^{\text {st }}$ Annual Meeting of the Society for American Archaeology, Orlando, Florida.

Gondwe, B. R. N., Ottowitz D., Supper, R., Motschka, K., Merediz-Alonso, G., BauerGottwein P., 2012, Regional-scale airborne electromagnetic surveying of the Yucatan karst aquifer (Mexico): geological and hydrogeologicalinterpretation:Hydrogeology Journal, 20, 1407-1425. https://doi. org/10.1007/s 10040-012-0877-8

Hanshaw, B. B., Back, W.,1980, Chemical masswasting of the northern Yucatan Peninsula by groundwater dissolution: Geology 8(5), 222-224. https://doi.org/10.1130/00917613(1980)8<222:GMOTNY>2.0.CO;2

King, Jr., D. T., Petruny, L.W., Pope, K.O., 2003,
Shallow marine facies of the Orange Walk Grou, Miocene-Pliocene, northern Belize (Central America) GCAGS/GCSSEPM Transactions, 53, 384-397.

King, Jr., D. T., Pope, K.O., and Petruny, L.W., 2004, Stratigraphy of Belize, North of the 17th Parallel. Gulf Coast Association of Geological Societies Transactions, 54, 289-304.

King,Jr., D. T., Petruny L.W., 2014, Stratigraphy of the Barton Creek Formation, Corozal Basin, Northern Belize: Gulf Coast Association of Geological Societies Transactions, 64, 215-228.

Leal-Bautista, R., Perry E.C., Cejudo, E.E., 2017, Reporte de campaña-zona 2: Felipe CarrilloCatmis-Chunhuhub, Quintana Roo, México, Centro de Investigación Científica de Yucatán Unidad de Ciencias del Agua, Reporte trabajo de campo.

Leal-Bautista RM., Perry E., Flores-Alvarado J., Alzate-Gavira L., Dominguez O.J., TapiaTussell, R., 2021, Karst Drainage of Lake Chakanbacán and its relation to Icaiche Formation: Boletín de la Sociedad Geológica Mexicana, 73(1), A021020. http://dx.doi. org/10.18268/BSGM2021v73n1a021020

López-Ramos, E.,1973, Estudio Geológico de la Península de Yucatán: Boletín de la Asociación Mexicana de Geólogos Petroleros, 25, 25-72.

Matheny, R.T., 1976, Maya Lowland Hydraulic Systems: Science, 193, 639-646.

Matheny, R.T., Gurr, D.L., Forsyth, D.W., Hauck, R., 1983, Investigations at Edzna, Campeche, Mexico: The Hydraulic System: Provo, Utah, USA, Papers of the New World Archaeology Foundation, Brigham Young University Press.

Marin, L. E., 1990, Field investigations and numerical simulation of ground-waterflow in the karstic aquifer of northwestern Yucatan, Mexico. Ph.D. Dissertation Northern Illinois University, DeKalb.

Ocampo, A. G., Pope, K.O., Fischer A.G., 1996, Ejecta blanket deposits of the Chicxulub crater from Albion Island, Belize: in G. 
Ryder, D. Fastovsky, and S. Gartner, eds., The Cretaceous-Tertiary event and other catastrophes in Earth history: Geological Society of America Special Paper 307, Boulder, Colorado, 75-88.

Parkhurst, D.L. 1995, User's guide to PHREEQC - A computer program for speciation, reaction-path, advective transport and inverse geochemical calculations. U.S. Geological Survey, Water Resources Investigations Report 95-4227, 143 p.https://doi. org/10.3133/wri954227

Pedersen, B. 2007, Aspects of the hydrogeology and geochemistry of the karst aquifer system, Yucatan Peninsula, Mexico. Ph.D. Dissertation, Northern Illinois University, DeKalb, IL.

Pérez-Ceballos R., Pacheco-Ávila, J., EuanÁvila, J.I.,Hernández-Arana, H., 2012, Regionalization based on water chemistry and physicochemical traits in the ring of cenotes, Yucatan, Mexico: Journal of Cave and Karst Studies, 74 (1) 90-102.

Perry, E. C., Velázquez-Olimán, G., Marin, L. E., 2002, The hydrogeochemistry of the karst aquifer system of the northern Yucatan Peninsula, Mexico: International Geology Review, 44(3),191-221. https://doi. org/10.2747/0020-6814.44.3.191

Perry, E.C., Paytan, A., Pedersen, B., VelázquezOlimán, G., 2009, Groundwater geochemistry of the Yucatan Peninsula, Mexico: constraints on stratigraphy and hydrogeology: Journal Hydrogeology, 367,27-40. https://doi.org/10.1016/j. jhydrol.2008.12.026

Perry, E.C., Velázquez-Olimán, G., Wagner, N., 2011, Groundwater and surface water geochemistry of $\mathrm{Cl}, \mathrm{SO}_{4}$, and $\mathrm{Sr}$ in Campeche and southern Quintana Roo, in Oswald, Ú. (ed.), Water Research in Mexico: Scarcity, Degradation, Stress, Conflicts, Management and Policy: Berlin, Germany, Springer-Verlag, 87-97. https:// doi.org/10.1007/978-3-642-05432-7
Perry, E.C., Leal-Bautista, R., Velázquez-Olimán, G., Wagner, N., 2018, The Icaiche formation: unacknowledged contributor to Yucatán hydrogeology and geomorphology, in The $130^{\text {th }}$ Annual Meeting of Geological Society of America in Indianapolis, USA paper 75.

Perry, E. G., Velázquez-Olimán, G., LealBautista R., Dunning N., 2019, The Icaiche Formation: Major contributor to the stratigraphy, hydrogeochemistry and geomorphology of the northern Yucatán peninsula, Mexico: Boletín de la Sociedad Geológica Mexicana, 71(3), 741-760. http:// dx.doi.org/10.18268/BSGM2019v71n3a7

Peterson, J.A., 1983, Petroleum geology and resources of southeastern Mexico, northern Guatemala, and Belize: U.S. Geological Survey Circular 760, 44 p., Alexandria, VA, USA.

Pope, K.O., Ocampo, A.C., Fischer, A.G., Vega, F.J., Ames, D.E., King Jr., D.T., Wachtman, R.J., Kletetschka, G., 2005, Chicxulub impact ejecta deposits in southern Quintana Roo, México, and central Belize: Geological Society of America Special Paper 384,171-190. https://doi. org/10.1130/0-8137-2384-1.171

Rosencrantz, E., 1990, Structure and tectonics of the Yucatan Basin, Caribbean Sea, as determined from seismic reflection studies: Tectonics, 9(5), 1037-1059. https://doi. org/10.1029/TC009i005p01037

Sánchez-Sánchez, J. A., Álvarez-Legorreta, T., Pacheco-Ávila, J., González-Herrera R.A., Carrillo-Bribiezca L., 2015, Caracterización hidrogeoquímica de las aguas subterráneas del sur del Estado de Quintana Roo, México: Revista Mexicana de Ciencias Geológicas, 32 (1), 62-76.

Sánchez, J. A., Álvarez-Legorreta, T., PachecoÁvila J.G., González-Herrera, R.A., CarrilloBribiezca L., 2016, Calidad del agua subterránea: acuífero sur de Quintana Roo, Mexico, Tecnología y Ciencias del Agua, 7(4), 75-96. 
Schulte, P., Alegret, L., Arenillas, I., Arz, J.A., Barton, P.J., Bown, P.R., Bralower, T.J., Christeson, G.L., Claeys, P., Cockell, C.S., Collins, G.S., Deutsch, A., Goldin, T.J., Goto, K., Grajales-Nishimura, J.M., Grieve, R.A.F., Gulick, S.P.S., Johnson, K.R., Kiessling, W., Koeberl, C., Kring, D.A., MacLeod, K.G., Matsui, T., Melosh, J., Montanari, A., Morgan, J.V., Neal, G.R., Nichols, D.J., Norris, R.D., Pierazzo, E., Ravizza, G., Rebolledo-Vieyra, M., Reimold, W.U., Robin, E., Salge, T., Speijer, R.P., Sweet, A.R., Urrutia-Fucugauchi, J., Vajda, V., Whalen, M.T., Willumsen P.S., 2010, The Chicxulub Asteroid Impact and Mass Extinction at the Cretaceous-Paleogene Boundary: Science 327 (5970), 1214-1218. http://dx.doi.org/10.1126/science.1177265

Servicio Geológico Mexicano (SGM), 2007, Carta Geológico-Minera, Estados de: Campeche, Quintana Roo y Yucatán, escala 1:500,000: 1 mapa, available at SERVICIO GEOLÓGICO MEXICANO www. coremisgm.gob.mx - INEGI, consulted on February 15 ${ }^{\text {th }}$ ，2017. (Update abril, 2018 https://www.gob.mx/sgm/articulos/ descarga-las-cartas-impresas-editadas-porel-sgm-70622?'idiom=es)

Southworth, C.S., 1985, Applications of remote sensing data, eastern Yucatan. In: Weidie, A.E. et al. (eds.), Geology and hydrogeology of the Yucatan and Quaternary Geology of northeastern Yucatan Peninsula. New Orleans Geological Society, New Orleans, LA, 12-19.

Socki, R. A., 1984, A chemical and isotopic study of groundwater from Northwestern Yucatan, Mexico. Ph.D. Dissertation, Northern Illinois University, DeKalb.

Socki R. A., Romanek C. S., Perry E. C., 2002, Stable isotope systematics of two cenotes from the northern Yucatan Peninsula,
Mexico: Limnology Oceanography, 47(6), 1808-1818. https://doi.org/10.4319/ lo.2002.47.6.1808

Stoessell, R. K., Ward, W. C., Ford, B. H., Schuffert, J. D.,1989, Water chemistry and $\mathrm{CaCO}_{3}$ dissolution in the saline part of an open-flow mixing zone, coastal Yucatan Peninsula, Mexico: GSA Bulletin, 101 (2), 159-169. https://doi.org/10.1130/00167606(1989)101<0159:WGACDI>2.3. $\mathrm{CO} ; 2$

Tulaczyk, S., Perry, E. C., Duller, C., Villasuso, M., 1993, Geomorphology and hydrogeology of the Holbox area, northeastern Yucatan, Mexico, interpreted from two LANDSAT TM images. In Applied Karst Geology, Proceedings of the Fourth Multidisciplinary Conference on Sinkholes and the Engineering and Environmental Impacts of Karst, B.F. Beck (ed.) Lisse, The Netherlands, AA Balkema, 181-188.

Velazquez, G., Perry, E., 2012, oral communication during a preliminary visit to the study zone.

Velazquez, L., 1986, Aplicación de principios geoquímicos en la hidrología kárstica de la Península de Yucatán. Ing. Hidráulica en México 1, 21-29.

Viniegra-O., F., 1981, Great carbonate bank of Yucatán, southern Mexico: Journal of Petroleum Geology, 3(3), 247-278. https:// doi.org/10.1111/j.1747-5457.1981. tb00930.x

Wagner, N., 2009, A geochemical study of the southern and northeastern Yucatan Peninsula, Mexico: DeKalb, IL., USA., Northern Illinois University, M.Sc. Thesis.

Weidie, A.E., 1985, Geology of Yucatan Platform. In: Weidie, A.E. et al. (eds.), Geology and hydrogeology of the Yucatan and Quaternary Geology of northeastern Yucatan Peninsula. New Orleans Geological Society, New Orleans, LA, 1-19. 